
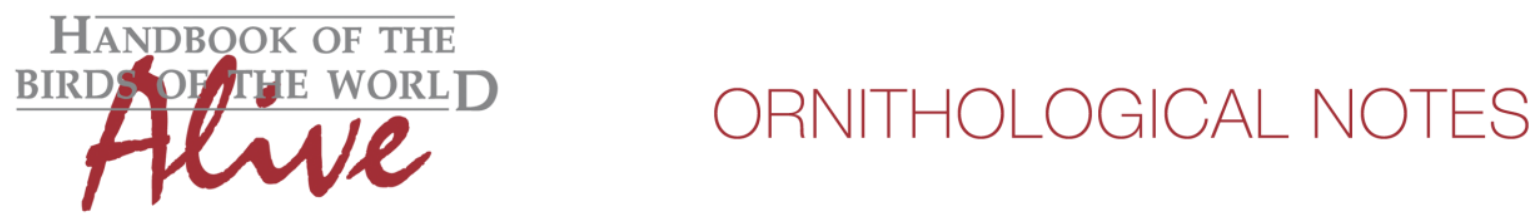

\title{
Notes on the vocalizations of Slaty-backed Chat-tyrant (Ochthoeca cinnamomeiventris)
}

Peter Boesman

In the following we briefly analyze and compare voice of the different races of Slaty-backed Chat-tyrant (Ochthoeca cinnamomeiventris). We also try to quantify the extent of any vocal differences using the criteria proposed by Tobias et al. (2010), as a support for taxonomic review. We have made use of sound recordings available on-line from Xeno Canto (XC).

Day-time song is a high-pitched whistle. When agitated this high-pitched whistle is followed by a series of notes. In the following we only compare the single high-pitched whistle (Fig. 1):

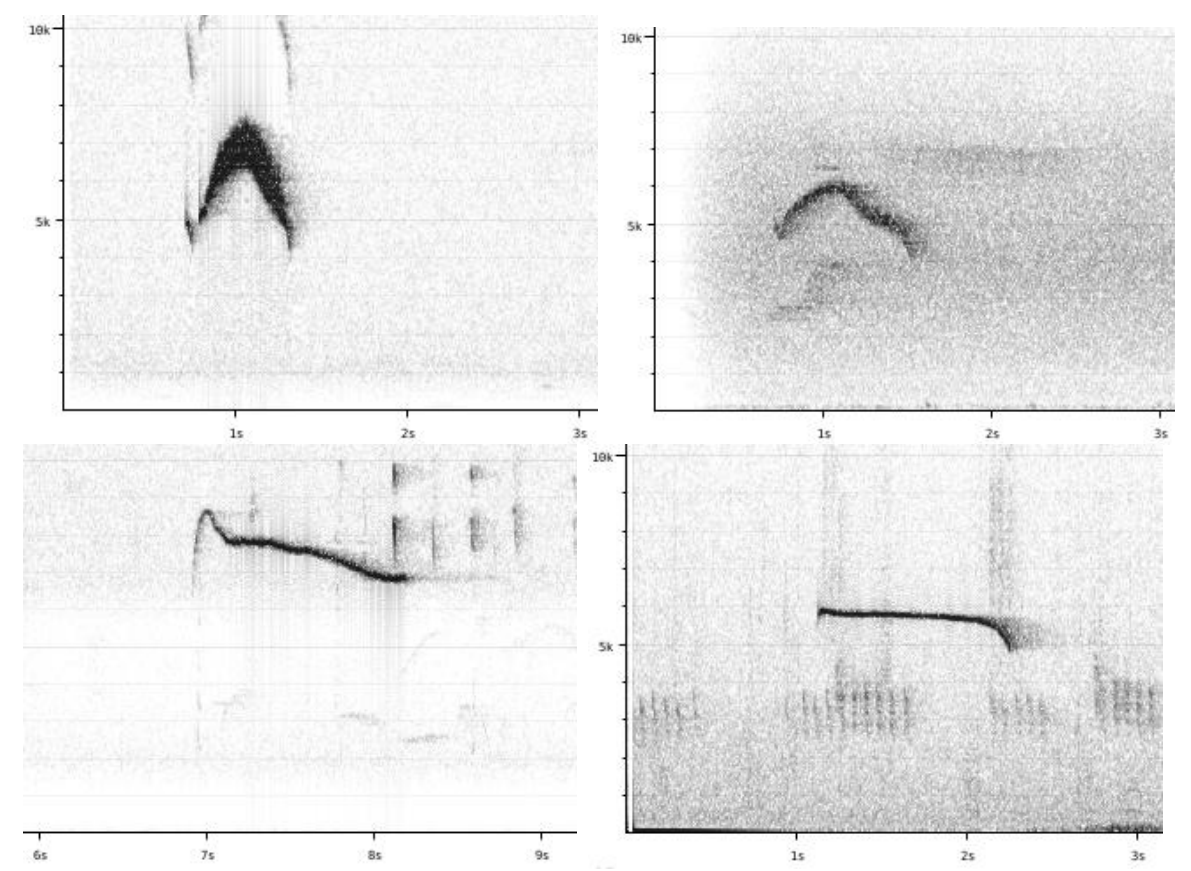

Figure 1: Typical whistle of cinnamomeiventris (top two examples, resp. from Ecuador and Colombia) and thoracica/angustifasciata (resp. bottom left and bottom right), illustrating the difference between and variation within both groups

O. c. cinnamomeiventris $(\mathrm{n}=9)$

min. freq. $\quad 3900-5000 \mathrm{~Hz}$

max. freq. $\quad 5800-7900 \mathrm{~Hz}$

freq. range $\quad 2000-3500 \mathrm{~Hz}$

total length $\quad 0.54-0.86 \mathrm{~s}$

note shape crescent-shaped, usually with some artefacts at start, and sometimes quite buzzy

O. c. angustifasciata and O. c. thoracica $(n=7)$

$\min$. freq.

$4700-6400 \mathrm{~Hz}$

max. freq. $\quad 5900-8300 \mathrm{~Hz}$

freq. range $\quad 600-1900 \mathrm{~Hz}$

total length $\quad 0.90-1.22 \mathrm{~s}$

note shape initially rising, then usually gradually descending

O. c. nigrita (0 recordings available) 

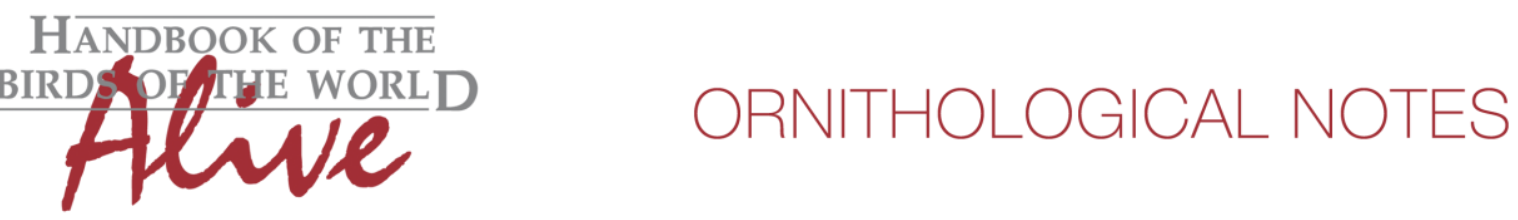

The whistled note of $O$. c. angustifasciata/thoracica clearly differs by its longer length (score 2), smaller frequency range (score 2) and slightly higher lowest frequency (score 1).

When applying Tobias criteria, this would lead to a total vocal score of 4.

Hilty (2003) decribes nigrita and cinnamomeiventris as two distinct species in his Venezuela guide, with voice descriptions that clearly indicate a difference. We haven't found any recordings to substantiate this difference, and unfortunately Hilty's (analog) recordings were not readily available (in litt.). We can thus only conclude there is probably also a vocal difference here.

This note was finalized on 10th July 2015 , using sound recordings available on-line at that moment. We would like to thank in particular the many sound recordists who placed their recordings for this species on XC.

\section{References}

Hilty, S.L. (2003). Birds of Venezuela. Princeton University Press \& Christopher Helm, Princeton \& London.

Tobias, J.A., Seddon, N., Spottiswoode, C.N., Pilgrim, J.D., Fishpool, L.D.C. \& Collar, N.J. (2010). Quantitative criteria for species delimitation. Ibis 152(4): 724-746.

\section{Recommended citation}

Boesman, P. (2016). Notes on the vocalizations of Slaty-backed Chat-tyrant (Ochthoeca cinnamomeiventris). HBW Alive Ornithological Note 253. In: Handbook of the Birds of the World Alive. Lynx Edicions, Barcelona. (retrieved from http://www.hbw.com/node/932254 on 4 October 2016). 